\title{
Rjavenje borovih iglic, Mycosphaerella dearnessii
}

\section{Dušan JURC}

Junija 2008 smo v Zdraviliškem parku na Bledu (ne enem drevesu rdečega bora), pri hotelu Jadran (na dveh grmih rušja) in ob Blejskem jezeru (na nekaj grmih rušja) ugotovili močno okužbo lanskoletnih iglic $\mathrm{z}$ glivo Mycosphaerella dearnessii, ki povzroča bolezen rjavenje borovih iglic. Gliva je uvrščena na EPPO A2 listo in je na prilogi Direktive sveta št. 2000/29/ES (Škodljivi organizmi, za katere ni znano, ali so navzoči $\mathrm{v}$ skupnosti, in ki so pomembni za vso skupnost) II/A1 (tam je navedena z imenom Scirrhia acicola). Bolezen je karantenska in zato jo je Fitosanitarna uprava RS dolžna kontrolirati. Pregledali smo bore na Bledu, v okolici kampa Šobec in v okolici golf igrišča Bled, vendar tam simptomov bolezni nismo našli. Značilnosti bolezni prikazujeta sliki 1 in 2 .

Doslej smo ugotovili: 1) Bolezen je na pregledanem območju zelo različno prizadela posamezne vrste borov in zelo različno tudi posamezne osebke iste vrste. 2) Razširjenost bolezni je majhna (nakaj $100 \mathrm{~m}$ ) in na osnovi teh ugotovitev smo predlagali Fitosanitarni upravi RS naslednje:

1) Takojšnje uničenje s sežiganjem vseh okuženih dreves in opada (odmrle iglice).

2) Monitoring pojava bolezni $v$ naslednjih letih.

Bolezen na terenu zelo lahko zamenjamo z boleznijo rdeča pegavost borovih iglic (Mycosphaerella pini (sin. Scirrhia pini, A: Dothistroma pini)), zato je za pravilno determinacijo nujno mikroskopiranje vzorca. Pri tej bolezni je značilna rjavo rdeča obarvanost dela iglice, navadno tam, kjer se oblikuje trosišče (slika 3), vendar to znamenje ni vedno prisotno. Nedvoumno jo določimo po mikroskopskih značilnostih trosov, ki nimajo debele, bradavičaste površine in so brezbarvni (ne rahlo rjavo do olivno zeleno obarvani kot pri glivi M. dearnessii) (slika 4).

ZGS bo najverjetneje vključen $\mathrm{v}$ monitoring in iskanje bolezni na borih v sestojih v okolici Bleda.
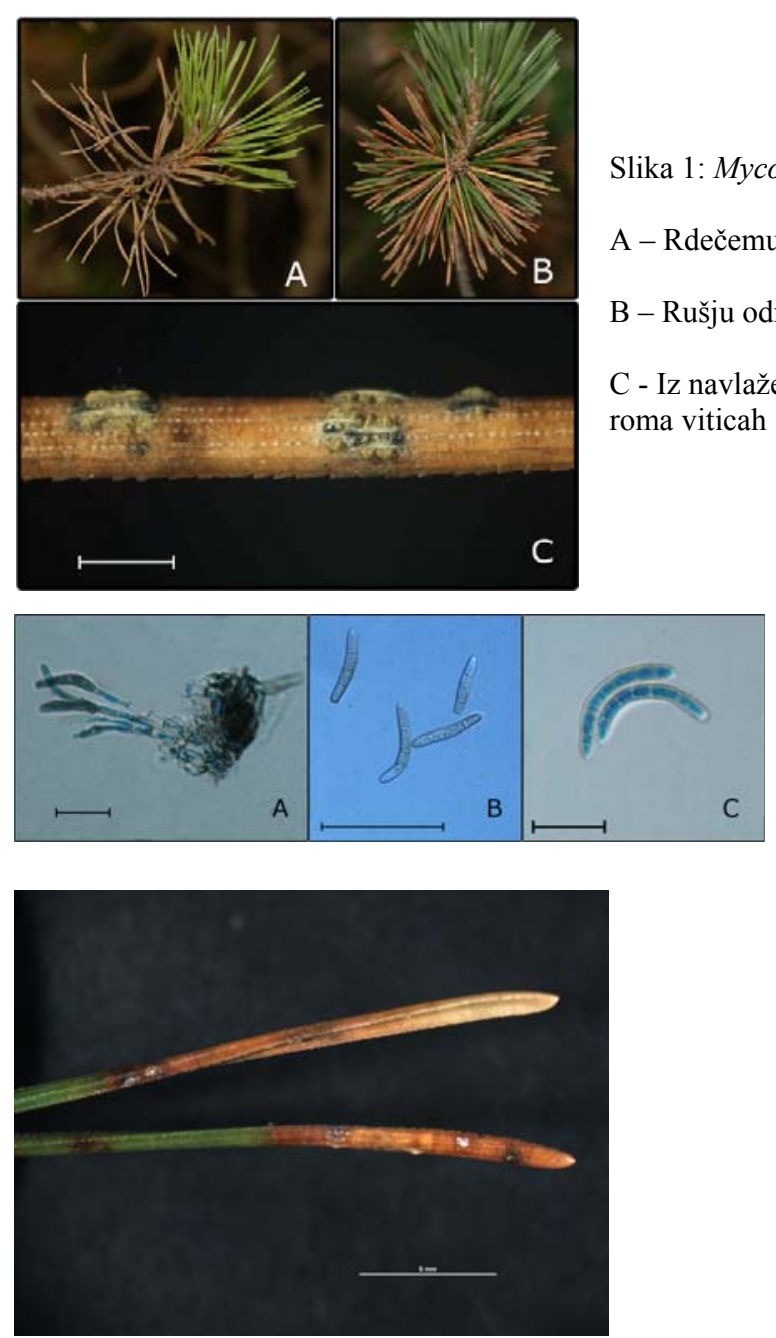

Slika 3: Mycosphaerella pini. Trosišča se oblikujejo na rdeči pegi na odmrli iglici rušja (črta $5 \mathrm{~mm}$ )
Slika 1: Mycosphaerella dearnessii

A - Rdečemu boru so odmrle lanskoletne iglice

B - Rušju odmirajo lanskoletne iglice

C - Iz navlaženih odmrlih iglic se konidiji izločajo v olivno zeleno-rjavih jezičkih oziroma viticah
Slika 2: Mycosphaerella dearnessii

A - Konidiogene celice so cevaste in dolge, na njih so nezreli konidiji (obarvano $\mathrm{z}$ lakto fenol bombažnim modrilom, črta $=20 \mu \mathrm{m}$ )

B - Konidiji v vodi, opazna je rahla rjava obarvanost, bradavičasta struktura površine stene, so ravni ali ukrivljeni (črta=50 $\mu \mathrm{m})$

C - Konidiji obarvani z lakto fenol bombažnim modrilom, dobro so opazne pregrade (septe) in debela stena (črta $=20 \mu \mathrm{m})$

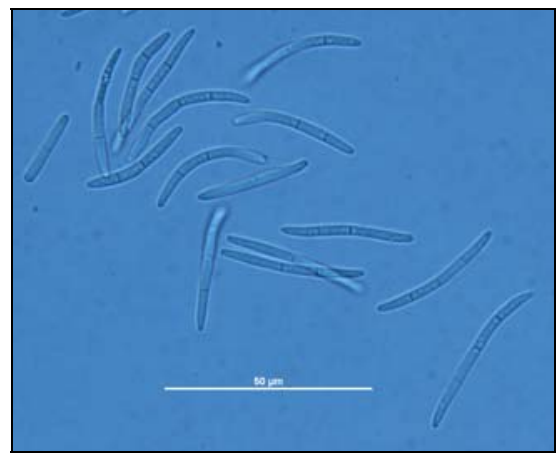

Slika 4: Mycosphaerella pini. Trosi nimajo debele stene, so gladki, vendar enako dolgi in septirani kot trosi pri glivi M. dearnessii 